\title{
Assessment of Mineral Status during the Peri-partum Period in Crossbred Cows
}

\author{
Anju Yadav ${ }^{1}$, M. M. Pathan ${ }^{2 *}$, S. P. Madhira ${ }^{2}$ and A. M. Pande ${ }^{3}$ \\ ${ }^{1}$ Department of Veterinary Physiology \& Biochemistry, College of Veterinary Sci. \& A. H., \\ $A A U$, Anand, India \\ *Corresponding author
}

\begin{tabular}{|l|}
\hline \multicolumn{1}{|l}{} \\
\hline Ke y w o r d s \\
Cow, Mineral, \\
Peripartum \\
\hline Article Info \\
\hline $\begin{array}{l}\text { Accepted: } \\
\text { 17 June 2020 } \\
\text { Available Online: } \\
\text { 10 July 2020 }\end{array}$ \\
\hline \hline
\end{tabular}

A B S T R A C T

The whole study was conducted on six adult pregnant, apparently healthy, Crossbred cows during Peripartum period i.e. from 45 days before parturition to 45 days after parturition. Nine $\mathrm{ml}$ of whole blood from each experimental animal was collected from jugular vein in heparinized vaccutainer. Plasma from the blood samples was separated and analyzed for mineral parameters. Concentration of calcium and zinc were observed to be significantly $(\mathrm{P}<0.05)$ lower on day 3 after parturition. Whereas, the concentration of magnesium and inorganic phosphorous were not differed significantly between pre-partum and post-partum period. Also the concentration of copper and Iron were observed to be significantly $(\mathrm{P}<0.05)$ lower on the day of parturition than any other days of the peri-partum period.

\section{Introduction}

The metabolic adaptation occurs during the transition period include a complex interaction between the energy supply, the protein indicators and the necessary minerals to guarantee structural functions, the restart of reproductive activity and the dynamism of the immune system. This generates homeostasis, which allows production and preservation of health (Leblanc, 2010). Adequate amount of trace minerals and vitamins, nutrition during the peripartum period is essential for an effective antioxidant defence system. It plays an important role in optimizing the immune responses and in helping the dairy cows to cope up with the stress of early lactation (Spears and Weiss 2008).

Peripartum cows with inadequate calcium (Ca), phosphorus (P) and magnesium $(\mathrm{Mg})$ concentrations in their blood experience loss of muscular and nerve function, decrease in food intake, low ruminal activity and decline of intestinal motility (Goff, 2006). Calcium plays an important role in utilization of 
cholesterol by mitochondria or by stimulating the conversion of pregnenolone to progesterone. GnRH stimulates $\mathrm{LH}$ release from pituitary cells involves a Ca-dependent mechanism. Phosphorus is often associated with reproductive abnormalities in cattle. The role of calcium and phospholipid-dependent protein kinase and c-AMP-dependent protein kinase may be crucial in mediating hormone action. Magnesium is equally essential in all enzyme reactions catalyzed by ATP and in maintaining the physical integrity of RNADNA (Patel et al, 2015). In view of the above facts an investigation was planned to assess the status of some crucial minerals during peripartum period on Crossbred cows.

\section{Materials and Methods}

The whole study was conducted on six adult pregnant, apparently healthy, Crossbred cows during Peripartum period i.e. from 45 days before parturition to 45 days after parturition. The research was approved by the Institutional animal Ethics Committee (IAEC.No.235/VBC/2016). The experimental animals were reared in semi-open housing system which is made up of concrete floor under asbestos roofed housing system constructed east west direction and well covered with trees. These experimental cows were not separated from other cows. The experimental animals were maintained on ICAR feeding standard (1998).

Nine $\mathrm{ml}$ of whole blood from each experimental animal was collected from jugular vein in heparinized vaccutainer. The blood was collected from 45 days before parturition at weekly interval i.e. -45day,38day,-31day, -24day, -17day, -10day,-3 day, on the day of parturition and upto 45 days after parturion i.e. on +3 day , +7 day, +10day, +15 day, +30day and +45day in accordance with the probable date of parturition. Plasma from the blood samples was separated by centrifugation at $3000 \mathrm{rpm}$ for 15 minutes and stored in deep freeze at $-20{ }^{\circ} \mathrm{C}$ until analyzed for mineral parameters. Plasma mineral estimation were carried using Diagnostic kits manufactured by Crest Biosystems, Coral Clinical Systems, Goa, by Spectrophotometer (model Visiscan 167). The data obtained in the present study was statistically analyzed by the Completely Randomised Design (CRD). The statistical model for CRD with one observation per unit

$\mathrm{Yij}=\mu+\mathrm{ti}+\mathrm{eij}$

$\mu=$ overall mean effect

$\mathrm{ti}=$ true effect of the $\mathrm{i}$

th treatment

eij $=$ error term of the $\mathrm{jth}$ unit receiving ith treatment

\section{Results and Discussion}

A number of trace minerals are required for functioning of enzymes involved in the antioxidant defence system. Certain trace minerals may also affect immune cells via mechanisms distinct from antioxidant properties. So, different mineral levels were measured in dairy cows during prepartum and postpartum period. Mean \pm SE values of all Minerals were presented in Table 1.

The observed overall mean value of calcium $(\mathrm{mg} / \mathrm{dl})$ in crossbred cows was $8.725 \pm 0.31$ which ranged from $6.45 \pm 0.25$ to $10.25 \pm 0.66$ during the peripartum period. The level of calcium was lowest on day 3 after calving as compared to all other peri-partum days. The concentration of calcium was found to be highest on 45 days before calving. It decreased significantly $(\mathrm{P}<0.05)$ on 38 days before calving, then the values started increasing non-significantly from 31 days to 3 days before calving. On the day of parturition the calcium level started decreasing significantly $(\mathrm{P}<0.05)$ reaching the lowest value on day 3 and remained low upto day 10. 
From day 15 onwards the level of calcium differed non-significantly during the whole post-partum period.

Results of present experiment were in consonance with observations of Nessim (2010) in Baladi cows and Piccione et al., (2012) in Holstein Friesian cows. However, Alameen and Abdelatif (2012) observed that the serum Calcium level was not affected significantly by season and stage of pregnancy. While, Oniia and Coliber (2009) reported high level of calcium 5-6 days after parturition in HF cows. Reduction in serum $\mathrm{Ca}$ in at or soon after parturition might be an unavoidable mechanism in dairy cows, especially in aged cows (Horst et al., 1994; Goff et al., 1991) due to the expeditious loss of Ca by milk synthesis, and less efficiency of $\mathrm{Ca}$ absorption by the intestinal transcellular pathway (Horst et al., 1994) and inactivation of the bone $\mathrm{Ca}$ resorption pathway.

The observed overall mean value of copper $(\mu \mathrm{g} / \mathrm{dl})$ in crossbred cows was $84.64 \pm 4.71$ which ranged from $55.69 \pm 3.52$ to 113.10 \pm 12.89 during the peripartum period. The level of copper was lowest on the day of parturition as compared to all other peripartum days. During the pre-partum period the changes in the concentration of the copper values were non-significant. The concentration of copper was significantly $(\mathrm{P}<0.05)$ decreased on the day of parturition and significantly $(\mathrm{P}<0.05)$ increased on day 15 as compared to any other peri-partum day.

Results that are obtained from the present study were in consonance with the observation of Maurya et al., (2014) in crossbred Karan Fries cows. Whereas Jayachandran et al., (2013) did not observe any significant differences in copper levels between anestrous and regularly cyclic buffaloes. However, Chnadra and Agarwal (2009) observed that if the crossbred cows are supplemented with $\alpha$-tocopherol acetate during the dry period copper levels were significantly higher in the animals during the peripartum period. Setia et al., (1994) reported that copper level was little lower during early lactation than at calving or late lactation. However, Mehere et al., (2002) and Jacob et al., (2003), observed rising level of copper from day of calving till 4-6 weeks postpartum. The lower concentration of copper recorded at parturition followed by increasing trend after 4-5 weeks postpartum could be due to increased transfer of this nutrient across the placenta and haemodilution during late pregnancy and at calving, together with initiation of ovarian follicular activity postpartum, leading to high circulating estrogens which stimulates binding of copper with proteins in liver thereby increased concentration in plasma (Mehere et al., 2002).

The observed overall mean value of iron $(\mu \mathrm{g} / \mathrm{dl})$ in crossbred cows was $200.46 \pm 6.20$ which ranged from $170.61 \pm 6.32$ to $235.48 \pm 8.07$ during the peri-partum period. The level of iron was lower during pre-partum period in comparison to the post-partum period. The variations in the concentrations of iron during the pre-partum period including the day of parturition were non-significant. After parturition the level of iron started increasing significantly $(\mathrm{P}<0.05)$ from 3 day onwards reaching the highest value on 45 day of peri-partum period.

The results of the present experiment were in consonance with the observation of Maurya et al., (2014) in crossbred Karan Fries cows. Whereas Chandra and Aggarwal (2009) reported that the Iron concentrations in the peripartum period also differ significantly in summer and winter. The iron in blood is present mainly as haemoglobin $(\mathrm{Hb})$ in erythrocytes and as transferring in the blood plasma. Iron plays an important role in 
oxygen delivery to the tissues, and as a cofactor with several enzymes involved in energy metabolism and thermoregulation. The recorded decline in serum $\mathrm{Fe}$ during late pregnancy could be related to the great demand for this element by the foetus (Swenson et al., 1993). This is because $\mathrm{Hb}$ levels decrease during pregnancy due to transfer of $\mathrm{Hb}$ across the placenta and haemodilution. The mean serum iron concentration differed significantly in prepartum period and postpartum period. There was decreasing tendency of iron towards parturition. This may be because of utilization of iron by mammary gland. Azab and Maksoud (1999) also reported similar findings in Baladi goat.

The observed overall mean value of magnesium $(\mathrm{mg} / \mathrm{dl})$ in crossbred cows was $1.93 \pm 0.04$ which ranged from $1.62 \pm 0.08$ to $2.11 \pm 0.23$ during the peripartum period. The magnesium level was observed to be slightly decreased on the day of parturition than any other day during the peri-partum period, but the decrease in the level of magnesium was non-significant. A slight variation in the magnesium value was observed throughout the peri-partum period but these variations were non-significant.

Results of present study were in consonance with observations of Oniia and Colibar (2009) in HF cows, Patel et al., (2015) also observed that in post-partum period the magnesium level of anestrus and subestrus cows did not differ significantly. Alameen and Abdelatif (2012) found that stage of pregnancy had no significant effect on magnesium level in crossbred dairy cows. Whereas Piccione et al., (2012) found that the physiological phase such as late gestation, post-partum, early lactation and late lactation have a significant effect on the magnesium levels in Holstein Friesian cows. However, Ghanem et al., (2012) observed a significant $(\mathrm{P}<0.05)$ decrease in magnesium concentration during the peri-parturient period of Friesian cows. In the present study a non-significant reduction in serum $\mathrm{Mg}$ level during late preganancy and lactation was observed. Several factors associated with diet composition can influence utilization and bioavailability of serum minerals. Serum Mg concentration is influenced by dietary protein level as well as $\mathrm{Ca}$ and $\mathrm{P}$ in the diet (Underwood and Shuttle, 1999).

The observed overall mean value of zinc $(\mu \mathrm{g} / \mathrm{dl})$ in crossbred cows was $225.80 \pm 6.25$ which ranged from $180.85 \pm 12.02$ to 260.30 \pm 28.46 during the peri-partum period. Zinc levels were significantly $(\mathrm{P}<0.05)$ lowest on day 3 after calving as compared any other peri-partum days. The value of zinc was observed to be significantly $(\mathrm{P}<0.05)$ higher on 3 days before calving of the peri-partum period. As compared with the pre-partum period the value of zinc was significantly $(\mathrm{P}<0.05)$ low on the day of parturition. Lowest value of zinc was observed on day 3 which started increasing significantly $(\mathrm{P}<0.05)$ from day 15 onwards reaching the pre-partum values by day 45 .

The results of the present experiment were in consonance with the observation of Maurya et al., (2014) in crossbred Karan Fries cows. Whereas Chandra and Aggarwal (2009) reported that the zinc concentrations in the peripartum period also differ significantly in summer and winter. However, Jayachandran et al., (2013) reported that the zinc levels did not differ between anestrus and regular cyclic buffaloes in the post-partum period. At parturition, due to increased colostrogenesis, there is diversion of $\mathrm{Zn}$ from plasma pool towards mammary gland. Drop in serum $\mathrm{Zn}$ level at calving is also associated with an acute phase response due to inflammatory reaction in uterus. Stress at calving induces synthesis of metallothionein, a protein 
associated with $\mathrm{Zn}$ distribution that may scavenge hydroxide radicals (Prasad et al., 2004). As a consequence, $\mathrm{Zn}$ is redistributed from blood pool to other tissues such as liver
(Meglia et al., 2001). All the facts explain why level of zinc is reduced around peripartum period.

Table.1 Mean $( \pm$ SEM) values of minerals in crossbred cows $(n=6)$ during peripartum period

\begin{tabular}{|c|c|c|c|c|c|c|}
\hline Days & $\begin{array}{c}\text { Calcium } \\
\text { (mg/dl) }\end{array}$ & $\begin{array}{c}\text { Copper } \\
(\mu \mathrm{g} / \mathrm{dl})\end{array}$ & $\begin{array}{l}\text { Iron } \\
(\mu \mathrm{g} / \mathrm{dl})\end{array}$ & $\begin{array}{c}\text { Magnesium } \\
(\mathrm{mg} / \mathrm{dl})\end{array}$ & $\begin{array}{c}\text { Zinc } \\
(\mu \mathrm{g} / \mathrm{dl})\end{array}$ & $\begin{array}{c}\text { Inorganic } \\
\text { Phosphorous } \\
(\mathbf{m g} / \mathbf{d l})\end{array}$ \\
\hline-45 & $10.25^{\mathrm{a}} \pm 0.66$ & $84.64^{\mathrm{cd}} \pm 6.69$ & $170.61^{\mathrm{e}} \pm 6.32$ & $2.11 \pm 0.23$ & $236.07^{\text {cde }} \pm 18.79$ & $8.06 \pm 0.27$ \\
\hline-38 & $8.66^{\text {cde }} \pm 0.87$ & $90.56^{c} \pm 11.60$ & $184.34^{\mathrm{de}} \pm 11.72$ & $1.95 \pm 0.11$ & $237.30^{\text {bcd }} \pm 19.05$ & $7.74 \pm 0.43$ \\
\hline-31 & $9.20^{\mathrm{bcd}} \pm 0.60$ & $73.70^{\mathrm{de}} \pm 7.15$ & $191.46^{\mathrm{cd}} \pm 9.48$ & $2.09 \pm 0.07$ & $215.83^{\text {ef }} \pm 15.78$ & $7.86 \pm 0.41$ \\
\hline-24 & $9.93^{\mathrm{ab}} \pm 0.42$ & $93.99^{\mathrm{bc}} \pm 8.35$ & $190.40^{\text {cde }} \pm 10.28$ & $1.73 \pm 0.04$ & $223.76^{\mathrm{def}} \pm 14.70$ & $7.41 \pm 0.37$ \\
\hline-17 & $9.98^{\mathrm{ab}} \pm 0.35$ & $64.31^{\mathrm{et}} \pm 7.62$ & $175.81^{\mathrm{de}} \pm 5.94$ & $1.74 \pm 0.15$ & $257.60^{\mathrm{ab}} \pm 5.69$ & $7.19 \pm 0.40$ \\
\hline-10 & $9.46^{\mathrm{abc}} \pm 0.36$ & $82.28^{\mathrm{cd}} \pm 9.04$ & $176.68^{\mathrm{de}} \pm 9.09$ & $1.97 \pm 0.21$ & $233.32^{\text {cde }} \pm 15.25$ & $7.32 \pm 0.40$ \\
\hline-3 & $9.53^{\mathrm{abc}} \pm 0.56$ & $72.05^{\mathrm{de}} \pm 9.10$ & $185.09^{\mathrm{de}} \pm 9.09$ & $2.01 \pm 0.12$ & $260.30^{\mathrm{a}} \pm 28.46$ & $7.09 \pm 0.52$ \\
\hline $\mathbf{0}$ & $8.28^{\mathrm{de}} \pm 0.24$ & $55.69^{\mathrm{f}} \pm 3.52$ & $186.11^{\mathrm{de}} \pm 7.44$ & $1.62 \pm 0.08$ & $208.78^{\mathrm{fg}} \pm 10.56$ & $6.62 \pm 0.45$ \\
\hline+3 & $6.45^{\mathrm{f}} \pm 0.25$ & $64.35^{\mathrm{ef}} \pm 3.35$ & $212.14^{b} \pm 6.23$ & $1.70 \pm 0.06$ & $180.85^{\mathrm{h}} \pm 12.02$ & $6.91 \pm 0.78$ \\
\hline+7 & $6.66^{\mathrm{f}} \pm 0.35$ & $91.80^{c} \pm 10.04$ & $229.14^{\mathrm{ab}} \pm 6.56$ & $2.01 \pm 0.08$ & $191.01^{\mathrm{gh}} \pm 24.82$ & $7.61 \pm 0.67$ \\
\hline+10 & $7.80^{\mathrm{e}} \pm 0.74$ & $82.21^{\mathrm{cd}} \pm 8.35$ & $235.48^{\mathrm{a}} \pm 8.07$ & $2.06 \pm 0.11$ & $209.63^{\mathrm{fg}} \pm 23.73$ & $7.62 \pm 0.60$ \\
\hline+15 & $8.75^{\text {cde }} \pm 0.89$ & $113.10^{\mathrm{a}} \pm 12.89$ & $209.55^{b c} \pm 11.09$ & $2.00 \pm 0.08$ & $222.92^{\mathrm{def}} \pm 12.38$ & $7.89 \pm 0.59$ \\
\hline+30 & $8.35^{\mathrm{de}} \pm 0.45$ & $108.55^{\mathrm{ab}} \pm 3.93$ & $224.07^{\mathrm{ab}} \pm 10.38$ & $2.06 \pm 0.05$ & $231.97^{\text {cde }} \pm 5.87$ & $8.01 \pm 0.56$ \\
\hline+45 & $8.75^{\text {cde }} \pm 0.36$ & $107.78^{\mathrm{ab}} \pm 6.83$ & $235.53^{\mathrm{a}} \pm 9.40$ & $2.05 \pm 0.06$ & $251.89^{\mathrm{abc}} \pm 7.07$ & $8.24 \pm 0.59$ \\
\hline GM & $8.72 \pm 0.31$ & $84.64 \pm 4.71$ & $200.46 \pm 6.20$ & $1.93 \pm 0.04$ & $225.80 \pm 6.25$ & $7.53 \pm 0.12$ \\
\hline CD & 1.56 & 23.18 & 25.41 & NS & 47.24 & NS \\
\hline $\begin{array}{c}\text { CV } \\
\%\end{array}$ & 15.59 & 23.78 & 11.03 & 15.33 & 18.75 & 16.96 \\
\hline
\end{tabular}

Values having different superscripts differed significantly $(\mathrm{P}<0.05)$ within column

The observed overall mean value of inorganic phosphorous $(\mathrm{mg} / \mathrm{dl})$ in crossbred cows was $7.53 \pm 0.125$ which ranged from $6.62 \pm 0.45$ to $8.24 \pm 0.59$ during the peri-partum period. The variation in the value of inorganic phosphorous was observed to be nonsignificant. The concentration of phosphorous was decreased slightly from 3 day before to day 3 post-partum but the changes were nonsignificant.

The results of the present experiment were in consonance with the observation of Roy et al., (2010) in cows. Whereas, Nessim (2010) reported that the Phosphorous levels increased significantly after calving in Baladi cows, Patel et al., (2015) observed that the level of phosphorous increased linearly throughout the post-partum period in subestrus HF cows. However, Alameen and Abdelatif (2012) found that phosphorous level was significantly $(\mathrm{P}<0.01)$ lower in winter in empty, early, mid and late pregnancy states and significantly $(\mathrm{P}<0.05)$ lower in mid and 
late pregnancy during summer in crossbred dairy cows. Ghanem et al., (2012) reported a significant $(\mathrm{P}<0.05)$ decrease in phosphorous concentrations during the peri-parturient period. This study results demonstrated no alterations in inorganic phosphorus values during the research period, which suggests that homeostatic mechanisms were effective.

Summary and conclusion are as follows:

Concentration of calcium and zinc were observed to be significantly $(\mathrm{P}<0.05)$ lower on day 3 after parturition. Whereas, the concentration of magnesium and inorganic phosphorous were not differed significantly between pre-partum and post-partum period. Also the concentration of copper and Iron were observed to be significantly $(\mathrm{P}<0.05)$ lower on the day of parturition than any other days of the peri-partum period.

\section{References}

Alameen, A. O., and Abdelatif, A. M. (2012). Metabolic and endocrine responses of crossbred dairy cows in relation to pregnancy and season under tropical conditions. American-Eurasian Journal of Agricultural and Environmental Science, 12(8): 1065-1074.

Azab, M. E., and Abdel-Maksoud, H. A. (1999). Changes in some hematological and biochemical parameters during prepartum and postpartum periods in female Baladi goats. Small Ruminant Research, 34(1): 77-85.

Chandra, G. and Agarwal, A., (2009) Effect of DL-a-Tocopherol acetate on calving induced oxidative stress in periparturient crossbred cows during summer and winter seasons. Indian Journal of Animal Nutrition, 26: 204210.

Ghanem, M. M., Mahmoud, M. E., Abd ElRaof, Y. M., and El-Attar, H. M.
(2012). Metabolic profile test for monitoring the clinical, haematological and biochemical alterations in cattle during peri-parturient period. Banha Veterinary Medical Journal, 23: 13-23.

Goff, J. P. (2006). Macromineral physiology and application to the feeding of the dairy cow for prevention of milk fever and other periparturient mineral disorders. Animal feed science and technology, 126(3-4): 237-257.

Goff, J. P., Kehrli, M. E., and Horst, R. L. (1997). Periparturient hypocalcemia in cows: prevention using intramuscular parathyroid hormone. Journal of dairy science, 72(5): 1182-1187.

Horst, R. L., Goff, J. P., and Reinhardt, T. A. (1994). Calcium and Vitamin D Metabolism in the Dairy Cow1. Journal of dairy science, 77(7): 1936-1951.

Jacob, S. K., Philomina, P. T., and Ramnath, V. (2003). Influence of gestation and early lactation on serum levels of iron, copper and zinc in crossbred heifers. Indian Journal of Animal Science, 46(2): 245-48.

Jayachandran, S., Nanjappan, K., Muralidharan, J., Selvaraj, P., and Manoharan, A. (2013). Blood biochemical and mineral status in cyclic and postpartum anestrus buffaloes. Int. J. Food Agric. Vet. Sci, 3(1): 99-97.

LeBlanc, S. (2010). Monitoring metabolic health of dairy cattle in the transition period. Journal of reproduction and Development, 56(5): 529-535

Maurya, P. K., Aggarwal, A., Singh, S. V., Chandra, G., Singh, A. K., and Chaudhari, B. K. (2014). Effect of vitamin $E$ and zinc on cellular antioxidant enzymes in karan fries cows during transition period. Indian Journal of Animal Research, 48(2): 109-119.

Meglia, G. E., Johannisson, A., Petersson, L., and Waller, K. P. (2001). Changes in some blood micronutrients, leukocytes 
and neutrophil expression of adhesion molecules in periparturient dairy cows. Acta Veterinaria Scandinavica, 42(1): 139-150.

Mehere, Y. S., Talvelkar, B. A., Deshmukh, B. T., Nagvekar, A. S., and Ingole, S. D. (2002). Haematological and trace element profile during peripartum period in crossbred cows. Indian Journal of Animal Sciences, 72(2): 148-150.

Nessim, M. Z. (2010). Role of Some Hormones and Blood Components during Pregnancy and Post Partum Periods in Baladi Cows. Journal of Radiation Research and Applied Sciences, 3(4B): 1319-1334.

Oniia, P., and Colibar, O. (2009). Energy, protein and mineral profile in peripartal period at dairy cows. Lucrari Scienti. Med. Vet. 42 (2): 398-404.

Patel, P. M., Dhami, A. J., and Kavani, F. S. (2015). Plasma calcium, phosphorus and magnesium profile in postpartum cows following hormonal therapy. The Indian Journal of Animal Reproduction, 32(1): 43-54.

Piccione, G., Messina, V., Marafioti, S., Casella, S., Giannetto, C., and Fazio, F. (2012). Changes of some haematochemical parameters in dairy cows during late gestation, post partum, lactation and dry periods. Vet Med Zoot, 58: 59-64.

Prasad, A. S., Bao, B., Beck, F. W., Kucuk, O., and Sarkar, F. H. (2004). Antioxidant effect of zinc in humans. Free Radical Biology and Medicine, 37(8): 1182-1190.

Roy, S., Roy, M., and Mishra, S. (2010). Hematological and biochemical profile during gestation period in Sahiwal cows. Veterinary world, 3(1):26-28.

Setia, M. S., Duggal, R. S., Singh, R., and Singh, R. (1994). Distribution of trace elements in whole blood and blood plasma during late pregnancy and different stages of lactation in buffaloes and cows. Buffalo J, 10(3): 213-220.

Spears, J. W., and Weiss, W. P. (2008). Role of antioxidants and trace elements in health and immunity of transition dairy cows. The Veterinary Journal, 176(1): 70-76.

Swenson M.J., Reece, W.O.(1993). Duke's Physiology of Domestic Animals. 11th. Ed. Cornell University Press, Ithaca, NY, 518-527.

Underwood, E.J. and N.F. Shuttle. (1999) General Introduction. In: Mineral Nutrition of Livestock. (Editor: Underwood E.J.) CAB International.

\section{How to cite this article:}

Anju Yadav, M. M. Pathan, S. P. Madhira and Pande, A. M. 2020. Assessment of Mineral Status during the Peri-partum Period in Crossbred Cows. Int.J.Curr.Microbiol.App.Sci. 9(07): 2088-2094. doi: https://doi.org/10.20546/ijcmas.2020.907.242 